\title{
NOTES ON SPECIES OF THE TETTIGIAN GROUP OF ORTHOPTERA.
}

BY J. L. HANCOCK, CHICAGO,

An interesting addition to Crthopteran distribution in the. West Indies is the finding by Mr. R. J. Crew of the species Neotettix quadriundulatus, Redtenbacher, on the Island on Haiti.

Eight specimens, kindly presented to me, were taken around Port au Prince, and, as $\mathrm{Mr}$. Crew informs me, were "swept from plants along the banks of a small stream." I have identified this species, which was first described by Brunner and Reditenbacher, 1892 , from the Island of St. Vincent, West Indies, in "Proceedings of the Zoological Society of London," and an excellent figure is to be fourd on Plate xvi., fig. io. Here it is recorded as a Tettix, but subsequent study has shown its closer approximation to Neotettix, Hancock. Species of the latter genus occur on the mainland of the southern United States and Mexico. The above species was recorded "numerous" on the Island of St. Vincent. Mr. H. H. Smith found it at Chateaubelais, also at the south end of the island, near the sea, under decaying leaves. Brunner, 1893 , again records this species from the Island of Grenada, at Mount Gay Estate, Caliveny Estate, Balthazar, in "Orthoptera of the Island of Grenada," Proceedings Zoological Society of London.

From a series of Tettigidie kindly furnished me from Mexico by Mr. O. W. Barrett, I am able to describe two new species of the genus Tettigidea, Scudder :

Tettigidea jalapa, sp. nov.

Rather large. Eyes prominent. Above fusco-ferruginous, dark fuscous over entire face and the sides, the last few segments at the end of the abdomen pale, legs pale throughout, the maxillary palpi a little depressed apically and very light, below the edges of prominent points and abdominal rings light. Body long, granulate. Vertex a little wider or subequally broad with an eye; nearly flat, hardly advanced in front of the eyes, widening posteriorly, the front border very little convexed, passing latteriy into small rounded and somewhat elevated carinæ ending abruptly near the anterior inner border of the eye; on either side and just behind are the very small lobes situated about the middle inner margin of the eyes in small sunken fossæ; mid-carina rather thin, extending backwards only as far as the ending of the lateral carinæ, but very little elevated, in front insensibly coalescing with the frontal costa; 
in profile the apex obtusely rounded angulate, the frontal costa depressoconvexed in front of the eyes and advanced in front of the eyes about one-fourth their width; below the face is moderately declined; as seen in front the frontal costa is strongly sulcate, the branches commencing near the apex in front are gradually divergent to the middle ocellus, where they are more than usually separated. Eyes very prominent and globose Antenna very slender, reddish, inserted a little above and in front of the anterior inferior border of the eyes. Pronotum anteriorly angulate, the sides substraight, posteriorly long and subulate: the apex acute, passing the posterior femora; dorsum smoothly granulate, with no longitudinal wrinkles, or scarcely a vestige of vein-like arrangement of the granules between the shoulders; median carina distinctly elevated, nearly straight or gradually arched a little higher between and a little in front of the shoulders ; humeral angles very obtuse, surface of dorsum between them tectiform; the anterior carinæ are curved, becoming a little divergent posteriorly; the borders of the posterior angle of the lateral lobe nearly form a right angle, acute at the apex; the posterior margin is straight and vertical. The elytra are nearly smooth externally, with a short thick oblique pale line very near the apex. Femora normal, the anterior and middle femora somewhat slender ; the posterior femora rather broad, the first article of the posterior tarsus equals the third in length; the pulvilli subrounded below, the third is little the longest.

Length: body, $\delta, 12 \mathrm{~mm}$, pronotum $\mathrm{I} 3 \mathrm{~mm}$, post. fem. $7 \mathrm{~mm}$. The wings extend beyond the apical process of the pronotum one millimetre.

Locality: Jalapa, Vera Cruz, Mexico, 4000 ft. elevation. June, 1898 . O. W. Barrett.

Tettigidea chichimeca australis, form. nov.

Body rather small, fuscous, above ferruginous obscurely clouded with fuscous; face below the eyes light, spreading laterally over the lower portion of lateral lobes, pale underneath the abdomen; femora light, obscurely clouded; tibia a little more distinctly striped with fuscous. Vertex scarcely narrower than an eye, obtusely angulate in front, a little produced in front of the eyes, the front margin formed of little lateral carinæ directed obliquely backwards and ending near the anterior inner angle of the eye, where the eye is a little conically elevated, feebly sulcate on each side longitudinally, the little lobes not very distinct, middle carinated, posteriorly extending only as far as the lateral carinæ, anteriorly coalescing with the shining frontal costa; in profile the vertex is obtusely 
rounded, advanced in front of the eyes about one-third their breadth, the frontal costa convexed, the distance between the anterior margin of the frontal costa and that of the eyes widening considerably below; the face below imperceptibly continued and quite declined; the apex is strongly obtusely rounded. As seen in front, the frontal costa is sulcate rather deeply, commencing near the apex, the branches are from here to the middle ocellus sub-parallel, and not divergent as in jalapa. Pronotum with the dorsum anteriorly obtusely angulate, the sides a little convexed, posteriorly subulate acute, passing the hind femora; dorsum granulate, with an indistinct longitudinal wrinkle on either side running parallel with the humeral angles, otherwise scarcely rugose; median carina distinctly elevated, gradually but slightly arched between the shoulders, sloping to the front margin; anterior lateral carina near the front substraight and subdivergent posteriorly; humeral angles strongly sloping laterally, as seen in front obtuse, between the shoulders convexed, the median carina clouded with fuscous. Elytra almost smooth, dark externally, marked with a minute light oblique line near the apex. IVings extended beyond the apex of pronotum. Femora with the carina unchanged, the posterior femora quite large, the first and third articles of the posterior tarsi about equal in length, all the pulvilli of equal length.

Length: body, of, $9 \mathrm{~mm}$., pronotum $9.5 \mathrm{~mm}$., post. fem. $5.5 \mathrm{~mm}$. Wings extending about one millimetre beyond the process of pronotum, making the total length i I millimetres.

Locality: Cuernavaca Morelos, Mexico. May, r898. O. W. Barrett.

This species is so closely related to Tettigidea chichimeca, Sauss., that I place it as a dimorphic form.

\section{A NEW POPULAR NAME FOR CLISIOCAMPA DISSTRIA.}

For many years this insect has been popularly known as "the forest tent-caterpillar." During the past two or three years it has attracted much attention in New Hampshire, Vermont, and New York, from its ravages in maple forests, city or village maple shade trees, and in many orchards. In orchards it has often worked with its near relative, the apple tent-caterpillar (Clisiocampa americana). Every one who critically observes the habits of these two species of caterpillars soon discovers that "the forest tent-caterpillar" is a very misleading name for Clisiocampa disstria, because its caterpillars never make a tent, while the apple tent-caterpillars always do. Several who have seriously discussed these insects recently have felt the necessity of a new popular name for Clisiocampa disstria. Professor C. M. Weed, of New Hampshire, when writing his recent excellent bulletin on the pest, asked me to suggest some 